\title{
Miranda
}

Revue pluridisciplinaire du monde anglophone /

Multidisciplinary peer-reviewed journal on the English-

speaking world

$20 \mid 2020$

Staging American Nights

\section{Richard Somerset and Matthew Smith (dir.), Mapping Fields of Study: the Cultural and Institutional Space of English Studies}

Philippe Birgy

\section{OpenEdition}

\section{Journals}

Electronic version

URL: http://journals.openedition.org/miranda/23984

DOI: 10.4000/miranda.23984

ISSN: 2108-6559

\section{Publisher}

Université Toulouse - Jean Jaurès

\section{Electronic reference}

Philippe Birgy, "Richard Somerset and Matthew Smith (dir.), Mapping Fields of Study: the Cultural and Institutional Space of English Studies", Miranda [Online], 20 | 2020, Online since 19 March 2020, connection on 16 February 2021. URL: http://journals.openedition.org/miranda/23984 ; DOI: https:// doi.org/10.4000/miranda.23984

This text was automatically generated on 16 February 2021.

\section{cc)}

Miranda is licensed under a Creative Commons Attribution-NonCommercial-NoDerivatives 4.0

International License. 


\section{Richard Somerset and Matthew} Smith (dir.), Mapping Fields of Study: the Cultural and Institutional Space of English Studies

Philippe Birgy

\section{REFERENCES}

Richard Somerset and Matthew Smith (dir.), Mapping Fields of Study: the Cultural and Institutional Space of English Studies, (Nancy: Presses universitaires de Nancy - Editions universitaires de Lorraine, 2019), 354 p, ISBN-10 2814305328 


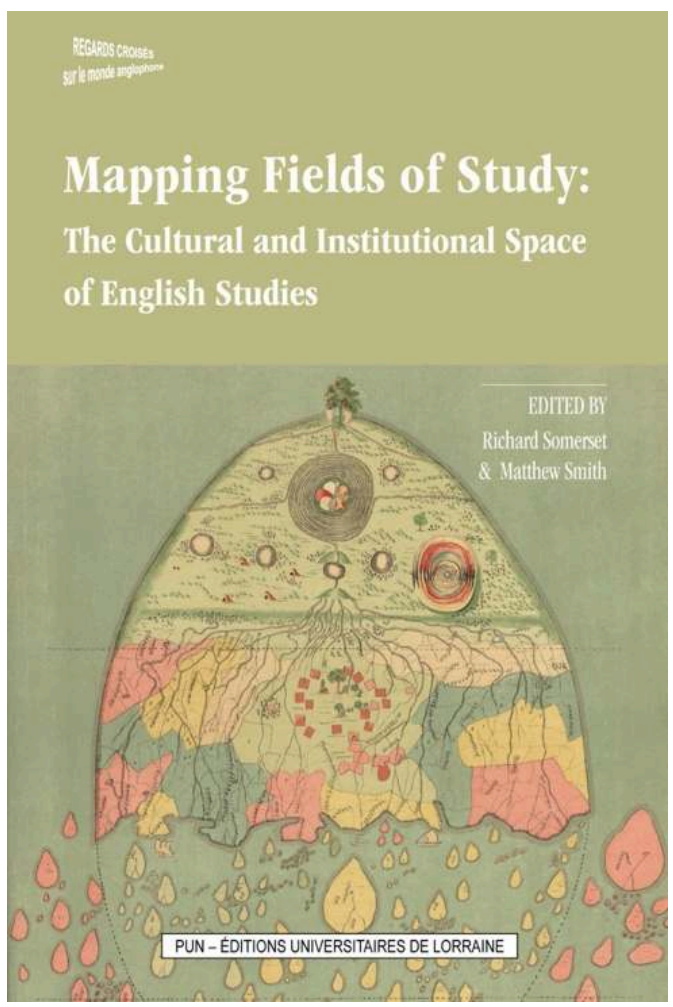

1 Mapping Fields of Study: the Cultural and Institutional Space of English Studies purports to account for the creation, structuring and evolution of English studies in the Englishspeaking world. In the introduction to the volume, Richard Somerset distinguishes three phases in their development. First, their structuration throughout the 19th and early 20th century on the model of the sciences. Then, the priority given to historicisation as a method after the Second World War (which mostly spread through academia in the sixties). Finally, a linguistic turn affecting the discipline in the nineties, under the influence of feminism and postcolonial studies, which recommended paying attention first and foremost to the elaboration of discourses.

of course, some might argue that neo-historicism (and neo-Marxism) have asserted themselves more preponderantly from the end of the eighties (as Somerset himself later indicates page 336), while the linguistic turn had been initiated at the beginning of the $20^{\text {th }}$ century, notably through the efforts of the philosophy of language practiced by Wittgenstein. Yet although this timeline may be disputable, one is needed at any rate, and no scholar will contest that, in the Humanities, there is no particular safety in numbers and figures.

The editors quite soundly insist on the necessity of taking into account, in their examination of English Studies as a discipline, its institutional and national contexts. They also remind us that histories of critical theory often omit to stress the dependence of this particular field of studies on other disciplines from which it derived its methods. All in all, it is the historical and social inscription of English that is foregrounded in the book and most of the contributions reflect this priority. Thus, the volume falls into three parts. The first one is devoted to the historical development of English studies in Great Britain while the second considers their evolution in anglophone speaking countries where the relevance of both the language and the 
contents may be questioned. Finally, the third part turns to the contemporary situation of the discipline.

4 Somerset notes the dominance in the book of a rather reserved outlook, as most authors recommend a retreat from the most radical critical positions currently upheld in sub-disciplines as varied as gender studies, cultural studies, and post-colonial studies, in order to allow a return to a certain original spirit of the humanities that rested on the close formal study of texts. But he simultaneously disclaims the suggestion that such a repositioning could be neutral: indeed, he explicitly acknowledges the political tenor of any disciplinary endeavor to secure a place in the field of the humanities.

5 In the opening article, Philip Riley's parses the procedures used in the nineteenth century to elaborate a scientific methodology, with particular attention to Darwin's contribution. After recapitulating the factors of modernity that bore upon the constitution of the scientific outlook, he observes the epistemological aspects of that modernity: eventually, the dividing line that separates the sciences from the humanities would be a matter of point of view: objectivism was set against the subjectivism of literary appreciations. Philip Riley also introduces other dichotomies to qualify and describe the forces that exerted themselves in the drawing of exclusive boundaries around the field of scientific inquiries: thus, the external stood in opposition to the internal, the sociological to the epistemological.

6 He then exposes the models offered by Biglan and Kolb to distinguish the distinctive features of the various fields of knowledge and explain their elaboration with reference to the theory of evolution (56) so as to account for the birth, development and death of disciplines. Riley also brings Simmel and Bourdieu to task, stressing the relevance of the notion of cultural capital, to better suggest an economical vision of academic disciplines where teachers offer products and services. He finally refers to Abbot's theory about the ramifications of disciplines informed by the "new paradigm" of chaos theory. According to it, the branching out of sub-disciplines reproduces fractally the same divisions at every level of the hierarchy of knowledge. In short, Riley provides a review of the main critical interpretations of the structuring and functioning of academic fields. This survey proves very useful insofar as it draws the general outlines of the subject before the reader delves into each specific study.

7 Somerset reconsiders the context of the argument between Thomas Huxley and Matthew Arnold which, arguably, established the scientific/literary divide and is read as the direct predecessor to the Snow Beavis "two cultures" debate of the late 1950s and 1960s. He highlights the incidence of political and institutional changes in the segregation of fields. And to give critical depth to this historical recapitulation of crucial moments in the process of discipline formation, he proposes to lean on thinkers who have taken an interest in the public sphere. Indeed, as he observes, since the language of science was not accessible to the lay public, the necessity of popularizing science in the public sphere ushered in the figure of the mediator. Unlike science, both philosophy and literature were perceived as disciplines whose language was unnecessarily complicated and it consequently failed to win public approbation.

8 Somerset contends that the Liberal intellectual elite who had replaced the aristocratic beneficiaries of superior education " $h[e] l d$ together a broad value-based cohesiveness in the face of the radical fragmentation of the knowledge landscape" (88). Thereby it conceived culture as an organic form which, the author remarks, reflected the tenet of 
liberal ideology. Somerset takes the example of Cuvier who claimed that from the fragments of a single bone of a primitive specimen, he could reconstitute the skeleton as well as the characteristics and habits of a whole extinct species. The same outlook came to determine the contemporary understanding of culture and of the nation as "undergirded by dynamic principles that shaped" them, thus comforting the liberal ideology which relied on progress and change. Hence the Arnoldian perception of cultural artifacts as "objects in flux". (94) Somerset then takes a survey of the education reform acts that modified the status of knowledge and disciplinary fields in Great Britain. Their general framework, he notes, kept sciences and humanities under a single heading.

9 Matthew Smith's article introduces a line of thought that will reappear now and again in the book. He begins by stating Eagleton's view according to which, when religion ceased to be the cement that held keep together the community, English was substituted to it, so as to provide a national discourse that exalted self-sacrifice and national pride. Smith, who does not subscribe to this vision of culture as an instrument to discipline and sedate the great bulk of the population, chooses the example of Henry Morley, who was instrumental in the emergence of English as a discipline, to demonstrate that the objectives of social control and nationalism were not the only motivations of educational reformers (136).

10 Angela Dustan's "Victorian Experiments in Reading Scientifically" completes this presentation of the historical background to the constitution of English Studies in Great Britain. She observes that the university's reticence to include literature in its programs resulted from the embarrassing proximity of the act of reading to a pleasurable activity. As a consequence, the seriousness of literature as work could be questioned. Freeman was one of the exponents of the idea that the analysis of texts was merely a matter of taste (157). In answer to these hesitations, Palgrave defined what he considered to be a scientific approach to literature that relied on method and rigor. Ironically, as Dustan observes, at about the same time, many proponents of English studies used literature to counter the advance of science on account of the larger breadth of knowledge it encompassed and the more humane dimension of its teachings.

11 In the second part of the book, devoted to the evocation of English Studies in multicultural contexts, Riaan Oppelt proposes to highlight "the closeness of English and English studies in South Africa to social change and identity". His chapter is concerned with institutions where other linguistic and colonial heritages dispute its position, which sets the problem of English as a vehicular language and the symbolical weight it is able to carry. In South Africa, embracing English is perceived as a form of faithfulness to an origin which becomes increasingly distant as generations succeed one another. Yet he also notices that "Black South African did [...] come to see English as the language of liberation after Apartheid" (185). (Moreover, Opplet questions the place the discipline can occupy in universities which are increasingly oriented towards vocational training).

12 After having evoked the history of the discipline from the settlement of the first English-speaking university in Cape Town to the adoption of business models in the $21^{\text {st }}$ century, he examines the cases of three different universities to suggest both the variety of responses and adaptation to contemporary contexts and the common problematics to which they are confronted. 

the main way of accessing employment in administrations and big companies, a symbolical capital as it were (212). Gosh remarks that the discipline, with its stress on moral values and some higher spiritual ground, nurtured a humanistic sensibility and an inclination towards freedom and independence, while English also served as a lingua franca to overcome the linguistic fragmentation between various ethnic components of the population.

14

Yet concurrently, the choice of subject and authors remained conservative. The incorporation in the syllabi of Indian Literature in English Translation in the 1980s was, according to the author, only a partial concession to the cultural realities of the attendees. As it is, the predominance of the English canon still remains palpable and evinces concerns that such a situation encourages a textbook culture not conducive to the personal critical involvement of the students in the discipline. Gosh also mentions the problem set by the continuation of this tradition when the number of colleges has soared and the level of language skills of the students is insufficient to guarantee an efficient pedagogical situation.

Lee Flamand, for his own part, focuses on identity politics on American campuses and their consequences on the choice of methods and subjects. He traces this orientation back to the impact on the university of the social movement of the 1960s which still determines its priorities, as it opened up its curriculum to embrace new objects of study. Flamand also underscores the connection with the Birmingham school of British cultural studies which was consonant with the project of the new left. The author illustrates his point through a study of a TV series dealing with campus racism, highlighting the series' insistence on the link between popular representations of race and gender and effective violence, one determining the other. As a result, the chapter is less directly concerned with English Studies proper, just as the one that follows it.

In the third part of the volume, Simon Tabet proposes to evaluate how English studies in American universities were affected by the joined influence of the linguistic turn, post-structuralism and postmodernism. The article actually concentrates mostly on the latter, and retraces the phases of the progress of that line of thought, drawing a historical line that originates with Toynbee and is prolonged by Charles Wright Mills, Fiedler and Sontag. The lineage, the author admits, is exclusively American. How exactly the story of the rise and triumph of postmodern thought in academia determined the contours of English Studies is not a subject addressed by Tabet, though partial answers to that question may be found in other parts of the book.

17 In "The Ghost of Literature: the Return of the Text in American Literary Studies", Constantinesco remarks that Postmodernism inaugurates a line of thought that is distinctly based on "post-identity politics" (293). He stresses the importance of reviews such as Boundary and Triquarterly in the propagation its ideas and assigns a prominent role to American essayists and theoreticians in their development.

Both Tabet and Constantinesco's texts are concerned with the American university. Yet its centrality to an assessment of English studies at the present time must certainly be qualified. (The inclusion in the second part of the volume of Flamand's study on identity politics in North American universities as an example of the global diffusion of English seems to suggest a different position). One may doubt, for instance, the existence of a concept of modernism that would be specifically North American (284). 
19 At this point, in spite of the precautions taken by the editor in the introduction, one may be under the impression that the dominant credo in the book points toward a project of restoration of the humanities to their former neutrality, once scholars and students have got over their compulsive habit of political historicisation (Constantinesco strangely exculpates Rancière from such politicization, presumably because of the personal and ethical orientation of his work). Perceiving and accounting for the subtle nuances of texts, recovering the many shades of the personal, reconnecting with the original intent of liberalism by being attentive to individual cases and profoundly humane certainly constitutes a laudable a project, but one that comes with its attendant sentimentalism, and this is what caused liberal minded intellectuals to fall behind the more enterprising and programmatic initiatives of the utilitarians and the socialists at the beginning of the twentieth century, both enlisting science in their service.

20 Constantinesco rightly notes the perpetual swing of the pendulum between formal textual studies and neo-historical, contextual studies in the history of the humanities, as taught and practiced at university. Admittedly, this swing of the pendulum is not likely to convince the advocates of science of the achievement of any progressive pursuit of knowledge in English studies. Indeed, if one does not find a way of preserving the lessons of the past, but keeps oscillating between mutually exclusive positions without keeping any record of the benefits of these moves, it might very well be that there is nothing more in the humanities than a series of passing whim. Getting beyond the systematic program of cultural studies may arguably be desirable, but the whole task of getting over and surmounting cannot be accomplished without passing through that which one wishes to surmount.

21 This passing impression of a disavowal of the developments of literary studies since the 1960 s is counterbalanced by Sumerfield's last contribution. Although the author equally sounds this note, charging postmodernism with facilitating a slide into "indifference to factuality", and stating that identity politics brought about an extreme fragmentation that rendered the humanities "increasingly irrelevant as a category of thought or a disciplinary building block" (337) he also reminds us of the historical process of adaptation that the discipline has gone through and insists on the determining role of historical methods in its development.

All in all, this is a book which does not offer a central thesis but rather proposes a series of critical assessments of the subject as well as a well-documented overview of the historical conditions of the formation of disciplinary borders. It shows them to be problematic from the onset, shot through by competing ideologies and permeated by a sense of insecurity. It manages to deploy a variety of standpoints that, whilst not being brought together in a dialogue, still form a coherent construction thanks to the punctual contributions of Richard Somerset which, from the introduction to the concluding essay, give a sense of unity to the volume. 
INDEX

Keywords: disciplinary field, English language, English studies, Great Britain, humanities, India, literary criticism, literature, South Africa, teaching, United States, university

Mots-clés: Afrique du Sud, champ disciplinaire, critique littéraire, enseignement, études anglaises, Etats-Unis, Grande Bretagne, humanités, Inde, langue anglaise, littérature, université

\section{AUTHORS}

\section{PHILIPPE BIRGY}

Professeur

Université de Toulouse - Jean Jaurès

birgy@univ-tlse2.fr 